\title{
A KUTATÁSALAPÚ KÉMIATANÍTÁS TANULÁSA
}

\section{LEARNING FROM THE INQUIRY-BASED CHEMISTRY EDUCATION}

\author{
Szalay Luca ${ }^{1}$, Tóth Zoltán ${ }^{2}$, Kiss Edina ${ }^{3}$ \\ 1PhD, egyetemi adjunktus, Eötvös Loránd Tudományegyetem Természettudományi Kar Kémiai Intézet, Budapest \\ luca@caesar.elte.hu \\ ${ }^{2} \mathrm{PhD}$, ny. egyetemi docens, Debreceni Egyetem Természettudományi és Technológiai Kar Kémiai Intézet, Debrecen \\ tothzoltandr@gmail.com \\ ${ }^{3}$ PhD, mesteroktató, Eötvös Loránd Tudományegyetem Természettudományi Kar Kémiai Intézet, Budapest \\ drkissed@chem.elte.hu
}

\begin{abstract}
ÖSSZEFOGLALÁS
Korábbi rövid, empirikus kutatásunk során széles körben használt receptszerű kísérletleírásokat alakítottunk át olyan tanulókísérletekké, amelyeknek egy vagy több lépését a 14-15 éves diákoknak kellett megtervezniük. Az eredmények azt mutatták, hogy sokuk hasznosítani tudta az így szerzett tudást. A jelenleg folyó projekt 2016 szeptemberében kezdődött. Ennek során négy évig vizsgáljuk a fenti megközelítés hatását a kutatásba bevont tanulók ténybeli tudására, kísérlettervező képességére és kémia tantárgyi attitűdjére. A munkát a Magyar Tudományos Akadémia Tantárgy-pedagógiai Programja keretében végezzük. 920 tanulót vontunk be a kutatásba, akik a vizsgálat kezdetekor 12-13 évesek voltak. A 7. osztályos diákok esetében a projekt első tanévében a tesztek eredményei nem mutatták a kísérlettervező képesség szignifikáns növekedését. Ezért a következő három tanévben a kísérleti csoportok feladatlapjai a kísérlettervezés fontosabb, az adott feladatokhoz kapcsolódó elveit is tartalmazták. A tesztekkel nyert adatok statisztikai elemzése azt mutatta, hogy ennek a beavatkozásnak már volt szignifikáns pozitív hatása a 8. osztályos tanulók kísérlettervező képességére. Ezeknek az eredményeknek Magyarországon és külföldön egyaránt jó visszhangja volt. Sajnos a koronavírus-járvány akadályozza az utolsó tanév tanulói feladatlapjainak kipróbálását és az utolsó teszt megírását. Azonban, reményeink szerint, a meghosszabbított projekt a 2020/2021. tanév első félévében sikeresen befejezhető lesz. A kutatócsoportunk e munka folytatására vonatkozó további terveit is ismertetjük.
\end{abstract}

\section{ABSTRACT}

In our earlier brief empirical research, established 'step-by-step' instructions were modified to practical activities requiring one or more steps to be designed by the 14-15 years old students. The results suggested that many of them benefited from the intervention. The present project has started in September 2016. In this longitudinal study, we investigate the effectiveness of the above approach for four years on the students' factual knowledge, experimental design skills and attitude toward chemistry. The work is funded by the Content Pedagogy Research Program of the Hungarian Academy of Sciences. 920 students have been involved, who were 12 to 13 years old at the beginning of the study. However, no significant development of the 
experimental design skills could be detected after the first school year of the project in the case of the $7^{\text {th }}$-garde students. Therefore, in the following three school years the student sheets of the experimental groups also contained the main principles of the experimental design related to the concrete tasks. The statistical analysis showed that the intervention had a significant positive effect on the development of the $8^{\text {th }}$-grade experimental groups in terms of experimental design. These results got positive feedback in Hungary and abroad. Unfortunately, the coronavirus pandemic has inhibited the piloting of the last year student sheets and filling in the last test. However, we hope that the extended project still can be finished successfully in the first semester of the school year 2020/2021. The research group also has further plans concerning how to continue the present work.

Kulcsszavak: kutatásalapú tanítás, kutatásalapú tanulás, kísérlettervezés, IBST, IBL

Keywords: inquiry-based teaching, inquiry-based learning, experimental design, IBST, IBL

\section{A KUTATÁSALAPÚ TANULÁS MÓdSZERÉN ALAPULÓ VIZSGÁLAT EREDMÉNYEINEK HOZZÁJÁRULÁSA A TARTÓSABB ISKOLAI KÉMIATUDÁS ÚJ HELYZETBEN VALÓ HASZNOSÍTÁSÁHOZ}

Az MTA-ELTE Kutatásalapú Kémiatanítás Kutatócsoport (URL1) a Magyar Tudományos Akadémia Tantárgy-pedagógiai Kutatási Programja (URL2) keretében jött létre. Megalakulása előtt a 9. osztályosok körében rövid távon sikerrel alkalmazott módszerünk (Szalay-Tóth, 2016) a jelen projekt első tanévében (7. osztályos tanulói mintán) nem okozott statisztikusan kimutatható fejlődést az év végi tesztet megíró 850 diák kísérlettervező képességének fejlődésében. Ezért a 2. tanév elejétől a projekt következő három évében kidolgozott feladatlapok segítségével közvetlenül is tanítjuk a kísérlettervezés elveit. A csoportmunkában tanulókísérleteket végző diákok mintegy harmada a kontrollcsoport, akik kizárólag receptszerü leírás alapján dolgoznak. A minta másik harmada az egyik kísérleti csoport, akiknek a receptszerü leírás alapján elvégzett kísérletek után a feladatlapok segítségével elmagyarázzuk, miért úgy kellett megtervezni és elvégezni a vizsgálatot. A diákok harmadik harmada pedig a kísérletek önálló megtervezéséhez és kivitelezéséhez kap elvi segítséget a feladatlapokon. Így a 8. osztály végén a kísérleti csoportok szignifikánsan jobban teljesítettek a kísérlettervezést igénylő feladatokban a csak receptszerüen leírt kísérleteket végző kontrollcsoporthoz képest. A 9. osztály végére azonban megállt a kimutatható fejlődés, sőt az egyik kísérleti csoport esetében visszaesést mértünk. Azt, hogy az utóbbi eredmény trend jellegü-e, milyen okai lehetnek, és ezek fényében a továbblépés lehetőségeit a jelen tanév végén a 10. osztályos tanulók által kitöltött tesztek elemzése után terveztük feltárni. Sajnos 2020. március 16-án a koronavírus-járvány miatt a teljes magyar közoktatásnak át kellett térnie a digitális oktatási módra. Ennek során a csoportos tanulókísérletekre épülö feladatlapjaink nyilvánvalóan nem próbál- 
hatók ki. A kutatásban részt vevő tanulók túlnyomó többsége pedig a 2020/2021. tanévben már nem tanul kémiát. A jelen tanulmány írásakor azonban azt reméljük, hogy ha a tanár kollégáink és diákjaik 2020 őszén visszatérhetnek az iskolákba, akkor megtalálják majd a módját (például biológiaórákon), hogy kipróbálják a hiányzó feladatlapokat, és kitöltsék az utolsó tesztet is.

\section{A KUTATÓCSOPORT MUNKÁJÁNAK NEMZETKÖZI ÉS HAZAI VISSZHANGJA}

A projekt 2019-ben beadott éves beszámolójának angol bírálója, Simon Lancaster professzor (University of East Anglia) szerint győzelemnek tekinthetö, hogy a kutatócsoportunk által fejlesztett tananyagok és módszertan statisztikusan szignifikáns eredményt tud felmutatni. Úgy véli, megfelelő disszeminációs stratégiát folytatva az eredményeknek nemzetközi hatásuk is lehet. A finn bíráló, Jari Lavonen professzor (University of Helsinki) véleménye az volt, a kutatócsoport a nemzetközi tantárgy-pedagógiai kutatócsoportok felső 10-20\%-ához tartozik. A 2019-es beszámoló anonim magyar bírálója pedig ezt írta: „A kutatócsoport olyan projektet kezdett el, amely mind időtartama, mind a bevont diákok létszáma alapján kivételesnek számít nemzetközi környezetben is... A módszertan megfelel a legszínvonalasabb pedagógiai kutatásokkal szemben támasztott elvárásoknak." A nemzetközi EUROVARIETY- és az ECRICE-konferenciákon, valamint az Eötvös Loránd Tudományegyetem (ELTE) Kémiai Intézetének Tudományos Napján és az Analitikai Kémiai Tanszék szemináriumán, továbbá az MTA Tantárgy-pedagógiai Programjának beszámoló konferenciáin (2017. 11. 15. Szegedi Tudományegyetem, 2018. 11. 7. Debreceni Egyetem, 2019. 11. 16. ELTE), valamint az Országos Neveléstudományi Konferenciákon (2017. 11. 9. Nyíregyházi Egyetem, 2018. 11. 8. ELTE, 2019. 11. 7. Pécsi Tudományegyetem) jelentős érdeklődés volt tapasztalható, és többnyire érdemi vita alakult ki az előadások és a poszterbemutatások kapcsán is. A projektben végzett munkáról a Chemistry Education Research and Practice folyóiratban 2020 elején jelent meg az első cikk (Szalay et al., 2020), ezért annak hatása még nem ítélhető meg.

\section{A HAZAI TANÁRI, ILLETVE NEVELÉSTUDOMÁNYI KÖRÖK REAKCIÓJA}

A munkába az eddigi négy tanév során bekapcsolódó, összesen harminckét gyakorló kémiatanártól gyüjtött és a kutatócsoportunk honlapján (URL3) is olvasható vélemények alapján minden fejlesztett és kipróbált feladatlapot javítunk, illetve módosítunk, mielött nyilvánosan elérhetővé tesszük őket a honlapunkon. A kollégák őszintén leírják a hibákat, és azt is, ha a feladatok például túl hosz- 
szúnak vagy bonyolultnak bizonyultak. Épp ezért merjük elhinni azt a sok, tőlük származó dicséretet is, amelyet a feladatlapok kaptak. Többször szerepelt olyan megjegyzés, hogy a kolléga a projekt lezárulta után is használni fogja az adott feladatlapot. A XXVI. Kémiatanári Nyári Továbbképzésen (2018. 8. 21. Eszterházy Károly Egyetem), valamint az Országos Neveléstudományi Konferenciákon (lásd fentebb), továbbá az akkreditált (2019. 7. 2-4. ELTE), valamint nem akkreditált tanártovábbképzéseken elhangzott pozitív reakciók közül e helyen csak egy elégedettségi kérdőívre írt véleményt idézünk: „Nagyon jó látni, hogy a többéves munkátok eredményeként valóban halad az IBST (Inquiry-Based Science Teaching, kutatásalapú tanítás, a szerzők megjegyzése) a hétköznapi megvalósítás felé.”

\section{A VIZSGÁLAT FOLYTATÁSÁNAK SZÜKSÉGESSÉGE}

A jelen tanulmány írásakor a projekt negyedik tanévének (10. osztály) végére tervezett teszt kitöltetése és értékelése tehát még hátravan. Jelenleg csak reméljük, hogy a koronavírus-járvány elmúltával 2020 őszén sikeresen le tudjuk zárni a projektet. Ehhez a projekt Támogatott Kutatócsoportok Irodája által engedélyezett, 2021. február 28-ig történő meghosszabbítása megfelelő alapot teremt. Azonban az már az eddigi eredmények alapján is nyilvánvaló, hogy - bár 8. osztályban valóban sikerült statisztikailag szignifikáns pozitív változást kimutatni a diákok kísérlettervező képességének fejlődésében - a hatással nem lehetünk maradéktalanul elégedettek. A fejlődés a 9. évfolyamon megtorpant, és a tanulók érdeklődésének, attitűdjének változása sem felel meg az előzetes várakozásoknak. Meggyőződésünk szerint a továbblépés iránya egyfelöl a módszer finomhangolása kell hogy legyen. Ez lehetne például a tanulók által a kísérlettervezés során állandóan követhető séma kialakítása és alkalmazása, amely a Julia Cothron és munkatársai által publikált (2000) könyv 6. fejezetében leírthoz hasonló is lehetne. Másrészt nagyon fontos volna megtalálni a módját annak, hogy a diákok a kémiatanulás négy éve alatt ne veszítsék el az érdeklödésüket a tantárgy által tárgyalt témák iránt. Ehhez vonzó módszernek tűnik a kémiaoktatási kutatások terén az utóbbi időkben elötérbe került „rendszerekben való gondolkodás", angolul systems thinking (Orgill et al., 2019). Az ennek során kialakítandó holisztikus látásmód a kémia tantárgyban vizsgált rendszereket nem egyszerüen a részeik összességének tekinti, hanem azok szerveződését és kölcsönhatásait, valamint a részeknek az adott rendszer tulajdonságait, viselkedését befolyásoló hatásait és a rendszer környezettel való egymásra hatását is figyelembe veszi. Vizsgálja, hogy mely változók és időben hogyan befolyásolják lényegileg a rendszer múködését. A világról filozófiai síkon éppen gondolkozni kezdő tinédzserek számára a kémia segítségével értelmezhető jelenségek ilyen fajta vizsgálata érdekes lehet (különösen akkor, ha annak környezetvédelmi vo- 
natkozásai is vannak). Azt azonban, hogy ezek a módszerek valóban sikerrel alkalmazhatók-e a magyar kémiatanítás mindennapi gyakorlatában, csak egy újabb longitudinális (hosszú távú) kutatással lehetne eldönteni. Ehhez pedig ismét célszerủ lenne egy több száz fônyi tanulóból álló minta kémiatanulását a 7. osztálytól a 10. osztályig a fentiekben leírt elvek alapján készített feladatlapokkal befolyásolni, és a hatást tesztekkel mérni.

\section{V. ÖSSZEHANGOLÁS A NEMZETI ALAPTANTERV KÉMIA TARTALMAIVAL}

A 2020. január 31-én a Magyar Közlönyben nyilvánosságra hozott Nemzeti alaptanterv (Nemzeti alaptanterv, 2020) kémia tantárgyra vonatkozó részébe szervesen beépültek a kutatócsoportunk által képviselt szemléletmód, illetve törekvések, amit az alábbi idézetek is bizonyítanak.

- A tantárgy tanitásának specifikus jellemzői a 7-8. évfolyamon címszó alatt olvasható a következő: „E célokat a tanuló számára releváns problémák, életszerü helyzetek kémiai vonatkozásainak tárgyalásával, a tanuló aktív közremüködésével, egyszerü - akár otthon is elvégezhetö - kísérletek tervezésével, végrehajtásával, megfigyelésével és elemzésével kell elérni. Az érdeklődés felkeltése és fenntartása érdekében célszerű a kémia tanítását, valamint az egyes témakörök tárgyalását is a tanuló számára érdekes problémák, kísérletek tanulmányozásával és megbeszélésével kezdeni." (392.)

- Mind a 7-8., mind a 9-10. évfolyamra elöírt általános követelmények között megjelenik a következő kitétel: „A nevelési-oktatási szakasz végére a tanuló... alkalmazza a természettudományos problémamegoldás lépéseit egyszerü kémiai problémák megoldásában.” (393., 395.)

- A 9-10. évfolyam általános követelményei között pedig szerepel, hogy a tanuló „kémiai vizsgálatainak tervezése során alkalmazza az analógiás gondolkodás alapjait és használja az »egyszerre csak egy tényezőt változtatunk« elvet" (395.).

\section{AZ MTA LEHETSÉGES SZEREPE A KUTATÁSOK TOVÁBBVITELÉBEN}

A kémia tantárgy-pedagógia kutatási területnek igen speciális, a kémiai tárgyú kutatásoktól eltéró jellemvonásai vannak. A szakmódszertani kutatási témák és módszerek általában sem illeszthetők jól az egyéb kutatási területekre szabott pályázati feltételekhez. A Magyar Tudományos Akadémia négy és fél tanéven át nyújtott támogatásának azonban nem csak az a kizárólagos szerepe, hogy biztos anyagi hátteret teremt a kutatócsoportunk munkájához. Óriási je- 
lentősége van annak is, hogy az MTA teljes súlyával és tekintélyével a magyar tantárgy-pedagógiai kutatások nemzetközi színvonalra emelése mellé állt. Úgy véljük, hogy ezzel a kutatócsoportunkat elindította azon az úton, amelyen feltétlenül érdemes továbbhaladni. Ehhez azonban a továbbiakban is feltétlenül szükség lenne az MTA támogatására.

\section{KÖSZÖNETNYILVÁNÍTÁS}

A tanulmány elkészítését a Magyar Tudományos Akadémia Tantárgy-pedagógiai Kutatási Programja támogatta.

\section{IRODALOM}

Cothron, J. H. - Giese, R. N. - Rezba, R. J. (2000): Students and Research: Practical Strategies for Science Classrooms and Competitions. $3^{\text {rd }}$ ed. Dubuque, IA: Kendall/Hunt Publishing Company

Nemzeti alaptanterv, 2020: A Kormány 5/2020. (I. 31.) Korm. rendelete a Nemzeti alaptanterv kiadásáról, bevezetéséröl és alkalmazásáról szóló 110/2012. (VI. 4.) Korm. rendelet módosításáról. Magyar Közlöny, 2020. január 31. 290-446. https://magyarkozlony.hu/dokumentumok/ 3288b6548a740b9c8daf918a399a0bed1985db0f/megtekintes

Orgill, M. et al. (2019): Introduction to Systems Thinking for the Chemistry Education Community. Journal of Chemical Education, 96, 12, 2720-2729. DOI: 10.1021/acs.jchemed.9b00169, https://pubs.acs.org/doi/10.1021/acs.jchemed.9b00169

Szalay L. - Tóth Z. (2016): An Inquiry-based Approach of Traditional 'Step-by-Step' Experiments. Chemistry Education Research and Practice, 17, 923-961. https://pubs.rsc.org/en/content/articlelanding/2016/rp/c6rp00044d\#!divAbstract

Szalay L. - Tóth Z. - Kiss E. (2020): Introducing Students to Experimental Design Skills. Chemistry Education Research and Practice, 21, 331-356. https://pubs.rsc.org/en/content/articlelanding/2020/rp/c9rp00234k\#!divAbstract

URL1: Az MTA-ELTE Kutatásalapú Kémiatanítás Kutatócsoport bemutatása az MTA honlapján: https://mta.hu/tantargy-pedagogiai-kutatasi-program/mta-elte-kutatasalapu-kemiatanitas-kutatocsoport-107088

URL2: A Magyar Tudományos Akadémia Tantárgy-pedagógiai Kutatási Programjának bemutatása: https://mta.hu/tantargy-pedagogiai-kutatasi-program

URL3: Az MTA-ELTE Kutatásalapú Kémiatanítás Kutatócsoport honlapja: http://ttomc.elte.hu/ publications $/ 90$ 